\title{
Anti-formalism and the Preordained Birth of Chinese Jurisprudence
}

\section{Samuli Seppänen}

\section{CpenEdition}

\section{Journals}

Electronic version

URL: http://journals.openedition.org/chinaperspectives/8446

DOI: 10.4000/chinaperspectives.8446

ISSN: 1996-4617

\section{Publisher}

Centre d'étude français sur la Chine contemporaine

Printed version

Date of publication: 31 December 2018

Number of pages: $31-38$

ISSN: 2070-3449

\section{Electronic reference}

Samuli Seppänen, «Anti-formalism and the Preordained Birth of Chinese Jurisprudence », China Perspectives [Online], 2018-4 | 2018, Online since 31 December 2019, connection on 24 March 2020 URL : http://journals.openedition.org/chinaperspectives/8446 ; DOI : https://doi.org/10.4000/ chinaperspectives.8446 


\title{
Anti-formalism and the Preordained
}

\section{Birth of Chinese Jurisprudence}

\author{
SAMULI SEPPÄNEN
}

\begin{abstract}
This article describes attempts in Chinese legal scholarship to produce indigenised forms of jurisprudence. These attempts are partly animated by an ethos of anti-formalism and the assumption that Chinese legal thought and the Chinese approach to adjudication are more flexible and more responsive to social concerns than (Western) legal formalism. Interestingly, prominent currents of European and American jurisprudence have made use of similar anti-formalist arguments since the beginning of the twentieth century. The anti-formalist impulse and the calls to indigenise Chinese jurisprudence are therefore best understood as performative strategies that support specific ideological projects, such as the effort to legitimise China's political status quo.
\end{abstract}

KEYWORDS: Chinese law, legal theory.

\section{Introduction}

In the past few years, the Chinese leadership and Chinese legal scholars have become increasingly vocal about the need to establish original "Chinese" approaches to jurisprudence, legal theory, and legal thought. In May 2016, Xi Jinping himself met with Chinese social scientists and legal scholars, urging them to develop "original theories based on China's practical conditions." (1) In the meeting, a representative from the legal field agreed that the "legal profession should strengthen its theoretical self-confidence by setting off from China's realities in order to examine and solve today's major theoretical and practical problems." (2) Efforts to indigenise Chinese jurisprudence have influenced the allocation of government research grants. ${ }^{(3)}$ In addition to state-sponsored attempts to develop indigenised forms of jurisprudence, a number of prominent Chinese legal scholars-especially those associated with the "New Left" and neo-conservativism — have promoted indigenised legal theories under various rubrics, such as sociological jurisprudence (jiang 2010; Zhu 2001) and New Confucianism (Xia 2011).

What precisely needs to be indigenised, if anything at all, is a matter of debate (Wang 2016; Xu 2016). Generally, calls for a Chinese "jurisprudence" (falixue 法理学) have pertained to theoretical and methodological matters, such as questions about the nature of law and legal research methods, as well as to theories of adjudication, which explain how judges decide disputes (Wang 2016). The term "legal theory" (faxue lilun 法学理论) is used synonymously with "jurisprudence" (Xu 2016), and with reference to both Western legal theory and ideologically loaded, theoretical descriptions of China's socialist legal system. ${ }^{(4)}$ The term "legal thought" (falü sixiang 法律 思想) refers not only to scholarly jurisprudence but also to existing modes of legal reasoning in the legal profession, which may or may not be theorised on the high level of academic jurisprudence (Deng 2008).

While there is much ambiguity about the precise objectives of these reforms, certain common features stand out in the attempts to develop indigenised forms of Chinese jurisprudence. These attempts are sometimes animated by an anti-formalist ethos. Anti-formalism effectively stands for the contention that legal thought in general, and theories of adjudication in particular, should be more responsive to social needs than what the mere application of formal law allows (Zhu 2016: 123). The anti-formalist sensibility is supported by the Chinese leadership's campaign against "formalism" as one of the "four forms of decadence," along with bureaucratism, hedonism, and extravagance. Formalism, in Xi Jinping's words, "means doing things for form's sake- - the separation of action from knowledge, neglecting what is truly effective, hiding behind piles of documents and immersing oneself in meetings, the pursuit of vanity and a resort to falsehood." "(5) Although Xi Jinping's comments were not made with direct reference to law, they have been cited by Party ideologues as an argument for increasing pragmatism in law enforcement. ${ }^{(6)}$ The anti-formalist sensibility also fits China's self-consciously pragmatic political philosophy, which the Chinese government now promotes in global forums. ${ }^{(7)}$

The author wishes to thank Rehan Abeyratne, Björn Ahl, and the two anonymous reviewers for their comments on this article.

1. "Xi stresses philosophy, social sciences for socialist development, highlights Chinese characteristics," Xinhua, 17 May 2016, http://news.xinhuanet.com/english/2016-05/17/c_135366343.htm (accessed on 2 November 2017).

2. “哲学社会科学工作座谈会发言摘编” (Zhexue shehui kexue gongzuo zuotanhui fayan zhaibian, Speeches in the symposium on the tasks of philosophy and social sciences), Renmin ribao, 18 May 2016, http://opinion.people.com.cn/n1/2016/0518/c1003-28358365.html (accessed on 1 November 2017).

3. See, e.g. " "中国法学会2017年度部级专项课题（董必武法学思想和中国特色社会主义法治理 论研究) 申报公告” (Zhongguo faxuehui 2017 niandu bu ji zhuanxiang keti [Dong Biwu faxue sixiang he Zhongguo tese shehuizhuyi fazhi lilun yanjiu] shenbao gonggao, China Law Society announcement for 2017 ministerial-level special subjects [research on the legal thought of Dong Biwu and the socialist rule of law with Chinese characteristics]), http://www.fxcxw.org/index.php/ Home/Xuejie/artIndex/id/15072.html (accessed on 17 November 2017).

4. "Speeches in the symposium on the tasks of philosophy and social sciences," art. cit.

5. Xi Jinping. 2014. The Governance of China. Beijing: Foreign Language Press: 405.

6. See e.g. Wang Dongjing 王东京, “从建设'法治浙江'到建设“法治中国'” (Cong jianshe 'fazhì Zhejiang' dao jianshe 'fazhi Zhongguo,' From building a 'Zhejiang rule of law' to building a 'Chinese rule of law'), Qiushi, http://www.qstheory.cn/zhuanqu/zywz/2015-04/13/c_1114942436.htm (accessed on 12 March 2018).

7. See the Chinese government advertisement in The Economist: Zhang Weiwei, "How China Made It: The Political Philosophy behind the World's Most Remarkable Success Story," The Economist, 10-16 March 2018, pp. 30-31. 
The legal theoretical move that characterises anti-formalist attempts to indigenise Chinese jurisprudence has been an integral part of global legal thought since the beginning of the twentieth century. Early-twentieth century legal theorists in France (Geny 1919), Germany (Jhering 1913), Scandinavia (Lundstedt 1956), the United States (Pound 1917), and many other Western and non-Western countries called for a new mode of jurisprudence that would be better suited to local social conditions than the received, supposedly formalist mode of legal thought. Anti-formalist jurisprudence supported the construction of welfare-state institutions and other interventionist state policies that had been resisted through formalist legal arguments (Kennedy 2003). As is the case with China today, twentieth century anti-formalism also had a vaguely nationalistic flair. Its advocates perceived their own legal systems to be more responsive to social concerns than the supposedly formalist legal systems of foreign countries (Kennedy 2003).

The anti-formalist attempt to indigenise Chinese jurisprudence therefore follows tried and tested global models. Prominent attempts to articulate forms of Chinese legal thought, such as the CCP's textbook on the socialist rule of law conception ${ }^{(8)}$ and scholarly examinations of anti-formalist research paradigms (Jiang 2003: 5; Zhu 2004: 7), have been made with explicit reference to the above-described early-twentieth century legal thought. Against this background, it seems unlikely that the mere aspiration to establish a socially responsive, anti-formalist form of jurisprudence would produce "original theories based on China's practical conditions," as requested by the Chinese leadership. ${ }^{(9)}$ Instead of reforming jurisprudence in China or anywhere else, a self-proclaimed reformist may well end up repeating old clichés about the importance of localised, socially responsive jurisprudence. This is not a problem for liberal-leaning Chinese legal scholars, who see no need for an indigenised Chinese jurisprudence (Xu 2016). However, the failure to provide indigenised legal theoretical insights is problematic for those CCP ideologues and scholars who are concerned about the appeal of liberal legal and political thought in China. ${ }^{(10)}$

This article describes Chinese legal scholars' attempts and frustrations in developing Chinese forms of jurisprudence, legal theory, and legal thought through anti-formalism. As mentioned above, other attempts at developing indigenous Chinese legal thought have been launched from Confucian traditionalism (Xia 2011) and neo-conservative ("New Leftist") critical scholarship (Deng 2008; Jiang 2003). I have discussed these strands of scholarship elsewhere (Seppänen 2014, 2016: 134-63). This article first describes antiformalist legal thought in a global context. It then proceeds to examine anti-formalism in Chinese legal thought and in Chinese theories of adjudication, which seek to operationalise legal thought by providing theoretical guidance for law application. This article finally discusses the possibility of indigenising Chinese jurisprudence in the context of China's ideologically divided legal academia. Conclusions are in the final section.

\section{Anti-formalism in global legal thought}

"Legal formalism," the bête noire of many theoretically ambitious legal scholars, is a contested term. As is the case with labels such as "socialism" and "liberalism," legal formalism is sometimes used as a term of devotion. Formalism stands for the assumption that legal rules are capable of restricting, and should restrict, decision-making. For a formalist, rules should restrict conduct even when, and especially when, they do not seem to serve public interests and their own presumed purposes (Schauer 1988: 510, 535). Rules are rules because they prevent decision-makers from considering factors that they would otherwise take into account. This is desirable because rules make it difficult to decide cases according to screened-off considerations, such as a person's race, gender, ethnic background, or some other criteria deemed undesirable by the enactors of the rule. As a social practice, formalism stands for "accountability, openness, and equality" (Koskenniemi 2001: 500). In a liberal democratic political system, a culture of formalism also supports the separation of powers doctrine by restricting the judiciary's authority to interpret rule-like norms (Manning 1999: 691). Advocates of formalism do not deny that decision-makers sometimes arrive at decisions without regard to rules. Their argument is that judicial behaviour is not, and should not be, characterised by a rule-breaking attitude (Schauer 1988: 530). A supporter of formalism may further point out that the virtues of formalism are uncontroversial in the legal community, and that it makes little sense to oppose formalism as a general category of legal theory or legal thought (Schauer 1988: 548; Stone 2002: 172). Indeed, as argued below, prominent Chinese critiques of formalism do not dispense with its underlying presupposition that legal rules should restrict decision-making powers. ${ }^{(11)}$

Despite its potential virtues, legal formalism is more commonly used as a derogatory label rather than a term of devotion (Schauer 1988: 510; Stone 2002: 166). Legal formalism was first identified as an object of scholarly critique by American, French, German, and Scandinavian sociological jurists at the turn of the nineteenth and twentieth centuries (Kennedy 2006: 40). According to sociological jurists, legal formalists had failed to appreciate (either unwittingly or cynically) the actual policy considerations involved in a legal matter. This was harmful for the public good, since the "law-inbooks," as opposed to "law-in-action," regularly failed to provide sound solutions for concrete social problems (Pound 1910). Another prominent form of criticism against legal formalism, particularly in the United States and Scandinavia, was presented by the so-called legal realist movement, which proposed to study legal institutions through empirical methods instead of textual analysis of formal law (Llewellyn 1930).

Both schools of thought-sociological jurisprudence (Pound 1910) and legal realism (Llewellyn 1930)—sought to demonstrate that the rule-like quality of law had been exaggerated in legal scholarship and that legal rules were "not the most useful center of reference for discussion" (Llewellyn 1930: 431). Much of this critique focused on a specific method of legal justification, which may be called textual formalism (Kennedy 2001: 8634). This technique, the critics argued, purported to decide cases by examining the literal meaning of a rule and applying this meaning to a given fact pattern. The textually formalist method allegedly denied or downplayed the role of choice in adjudication, and consequently ignored (or pretended to ignore) relevant contextual considerations (Kennedy 2001: 8634). An oftcited example is the notorious Gilded Age decision, Lochner v. New York, ${ }^{(12)}$ decided in 1905 (Schauer 1988: 511). In this decision, the United States Supreme Court held that federal restrictions on working hours were an unconstitutional limitation of the contractual freedom of American labour-

8. Central Political and Legal Committee of the Chinese Communist Party, 社会主义法治理念读本 (Shehui zhuyi fazhi linian duben, The socialist rule of law principle -A reader). Beijing: Zhongguo Chang'an chubanshe, 2009, 30.

9. "Xi stresses philosophy, social sciences for socialist development, highlights Chinese characteristics," art. cit.

10. The socialist rule of law principle $-A$ reader, op. cit: 40

11. See e.g. Ibid.: 64 .

12. Lochner v. New York, 198 U.S. 45 (1905). 
ers. ${ }^{(13)}$ To sociological jurists and legal realists (who included the dissenting judge in Lochner and the founder of American legal realism, Oliver Wendell Holmes), this form of legal reasoning was both disingenuous and unconvincing. No legal necessity, it was argued, required the Supreme Court to hold federal working time laws unconstitutional. "General propositions do not decide concrete cases," Holmes wrote in his famous dissent. ${ }^{(14)}$ In the critics' view, the Supreme Court had sought to advance laissez-faire economic policies behind the veil of formalist legal reasoning (Pound 1908: 615-6). ${ }^{(15)}$

In the United States and globally, sociological jurisprudence and legal realism became the legal means for attacking the political and economic system of the early twentieth century and its legal edifice (Horwitz 1992: 152). Contractual obligations and property rights, it was argued, should be determined in response to whatever concrete social ends and policies the legislature sought to achieve rather than through textual analysis of formal law (Holmes 1897: 465-6; Pound 1908: 221-2). This argument supported progressive lawyers' project to defend welfare state institutions and state interventions against conservative laissez-faire policies, and it proved effective from Egypt (Shalakany 2001: 162) to Sweden (Malminen 2007: 80-1) and the United States (Horwitz 1992: 194).

The influence of sociological jurisprudence was also felt in China during the same period. Sun Yat-sen's Three Principles of the People treated private property rights as means to promote the common livelihood rather than as formal individual entitlements. Private land rights, for instance, could be taxed or acquired by the government as the public good required (Sun 1927: 433). It says much about the global reach of sociological jurisprudence that Roscoe Pound, the Harvard Law School dean and the foremost figure in American sociological jurisprudence, served as a legal adviser to the Kuomintang in the 1930s and 40s. In this role, Pound purported to promote legal institutions that were based on "Chinese knowledge of Chinese conditions" (Kroncke: 211). ${ }^{(16)}$

In retrospect, much of the success of legal realism and sociological jurisprudence can be explained by its irreverent style, which suited the iconoclastic zeitgeist of the early twentieth century (Ackerman 1974: 125). Legal realists, in particular, promised a radical break from the tired conventions of the nineteenth century. With the wisdom of hindsight, sociological and legal realist critics of legal formalism can be seen to have overstated their case. The object of the sociological and realist critique, "legal formalism," may have been a strawman that was set up for an "effortless assault on undefended positions" (Stone 2002: 170). The supposedly formalist decision in Lochner v. New York, for instance, did in fact consider the social consequences of contractual freedom. ${ }^{(17)}$ By presenting a one-sided image of the court's reasoning in Lochner and other supposedly formalist decisions, sociological jurists and legal realists were able to position themselves as the avant-garde of legal thought and support progressive legislation as scientifically advanced legal institutions rather than as subjective political preferences. This argumentative strategy lost much of its global appeal in the 1960s and 70s, as legal scholars came to believe that the examination of social realities was insufficient for deciding matters of justice. In the latter part of the twentieth century, global legal thought turned towards procedural justice, fundamental rights, universal human rights, and constitutionalism (Kennedy 2003).

A more recent source of criticism against "formalism" in global legal thought originates in the Critical Legal Studies (CLS) movement, which has been influential in Chinese New Leftist scholarship (Wang 2006: 173). Dun- can Kennedy (1976), the founding father of the CLS movement, argues that the never-ending pull between formal rules and substantive standards makes it impossible to rely exclusively on either formalist legal rules or sociologically determined policies (Kennedy 1976). For every formalist argument there exists an anti-formalist argument, and vice versa. Formalism in global legal scholarship has also been attacked through legal pragmatism, a relatively small legal theoretical denomination that has nonetheless been embraced by prominent Chinese sociological jurists (Zhu 2016: 123). Pragmatism defines itself in opposition to legal formalism, which it takes to be a "slave of the past" (Posner 1996: 8). A pragmatist judge will not be confined to ensuring the consistency of past interpretations of formal rules (Posner 1996: 4). Instead, the judge looks for the "best" solution given the facts of a specific case (Posner 1996: 16; Zhu 2016: 123). While pragmatists reject formalism as the sole adjudicative technique, the analysis of the meaning of formal rules is part of the pragmatist decision-making process. Stability in law is "a genuine public good" (Posner 1996: 7), but in order to make the "best" decision, a judge will have to consider all relevant issues, and not just the meaning of formal legal texts.

\section{Anti-formalism in Chinese legal thought}

Chinese critiques on legal formalism build on the above-described global scholarship (Jiang 2010; Wang 2016; Zhu 2004). "Legal formalism" translates into Chinese as falüxingshizhuyi 法律形式主义, a term that can carry a positive or a negative connotation, just like the English language term "legal formalism." In addition to falüxingshizhuyi, the object of Chinese anti-formalist critique may also be described through the concept of fatiaozhuyi 法条主义. This is a negatively charged term, and best translated into English as "legal dogmatism." (18) As is the case with "legal formalism," fatiaozhuyi may be defined as "an attempt to build a regime or system of rules (...) that is relatively complete, logically self-consistent, convenient for communication and operationally valid" (Deng 2014: 216). ${ }^{(19)}$ The two terms, (falü) xingshizhuyi and fatiaozhuyi, can be used interchangeably in order to criticise excessively formalist decision-making. For instance, a textbook on the socialist rule of law conception published by the Central Political and Legal Committee of the CCP defines the legal thought opposed by American legal realists as fatiaozhuyi, while also warning party cadres against the dangers of xingshizhuyi. (20)

Anti-formalism takes various forms in Chinese legal thought. First, antiformalism is an approach (or part of an approach) to legal theory. In this sense, anti-formalism is meant to expose the shortcomings of mainstream formalist legal thought and point the way to a new, socially responsive jurisprudence. The most influential (although controversial) anti-formalist critique of China's mainstream jurisprudence has been put forth by Professor Zhu Suli, the former dean of Peking University School of Law. Zhu Suli was

13. Ibid. 64

14. Ibid. 76

15. Ibid. 75

16. Jedidiah Kroncke explains that, in reality, Pound ended up pressing his own progressive reform agenda without accepting the views of his Chinese hosts and without having much impact on Chinese law (Kroncke: 212, 221).

17. Lochner v. New York, op. cit. 57.

18. Fatiaozhuyi may also be translated into English language as "legalism," but this term is easily confused with ancient Chinese "Legalism."

19. I rely here on the English language translation of Deng's work.

20. The socialist rule of law principle - A reader, op. cit., pp. 34, 75-76. 
instrumental in introducing sociological jurisprudence and social scientific research methods into China in the 1990s. In Zhu's view, Chinese jurisprudence had "paid attention only to research on legal texts, but not to (...) informal systems," which informed how law actually operated in Chinese society (Zhu 2016: 49). Zhu's scholarship had the irreverent air of American Legal Realism, and it was experienced as provocative by liberal-minded and mainstream Chinese legal scholars, who objected to it vehemently ( $\mathrm{Xu}$ 2002). The anti-formalist argument implied that scholars who conducted doctrinal analyses of formal law, including its rights protections, were both socially out-of-touch and politically naive. This was an ideologically explosive argument, since Zhu's scholarship was associated with the neo-conservative defence of China's political status quo (Upham 2005).

As was the case with Western sociological jurisprudence and legal realism, the aim of Chinese sociological jurisprudence is not the wholesale disavowal of rule-based legal governance, which is of central importance to the CCP. (21) Instead, Chinese sociological jurists aim to identify legal and social institutions (whether formal or informal) that best suit China's "needs," however these needs may be defined. This project relies on the legal realist distinction between "law-in-books" and "law-in-action," and it presumes that some aspects of the Chinese "law-in-books" are potentially counterproductive for realising the Party's and the people's interests. Hence, Zhu maintains that "formal legal knowledge [has] quite a few conflicts with customs that are rather stable and prevalent in Chinese society" (Zhu 2016: xii). In order to account for useful social institutions and practices, Chinese legal scholars "need to look for native resources from all kinds of informal legal systems" (Zhu 2016: xiv). Chinese anti-formalism thus provides a political agenda and a research agenda. Zhu Suli, the paterfamilias of Chinese sociological jurisprudence, has conducted a number of influential sociological studies in the Chinese countryside, among other things, describing the pragmatic approach to adjudication in basic-level people's courts (Zhu 2016). In the 1990s and the 2000s, Zhu's disciples applied anti-formalist critique to various fields of law. Professor Jiang Shigong's work on informal, "unwritten" constitutional law is a prominent example of this genre of legal scholarship (Jiang 2010, 2014).

Second, anti-formalism in China exists as a legal theoretical argumentative strategy. Much like the sociological and realist critique of the Lochner decision, Chinese anti-formalism sets up a politically disagreeable viewpoint as a "formalist" position and then repudiates this viewpoint through a theoretically privileged anti-formalist position. In this (as such controversial) argumentative strategy, formalism stands for a bookish, socially out-oftouch approach to law, whereas the preferred, supposedly more progressive anti-formalist approach allows jurists to discover the actual "reality" of a legal issue. This argumentative strategy can be observed, for instance, in Jiang Shigong's discussion on the Communist Party's leadership role in Hong Kong, where Jiang was posted as a researcher in the central Chinese government's liaison office in the 2000s. Jiang first discusses the legal formalist understanding of the CCP's role in Hong Kong. "[F]rom the perspective of legal formalism," Jiang explains, "one has to distinguish in the Constitution between what belongs to 'one country,' which would apply also to Hong Kong, and what belongs to the 'socialist system,' which would not apply to Hong Kong" (Jiang 2010: 38). In Jiang's view such a formalist understanding of the role of the CCP in Hong Kong would run into conceptual difficulties. "[S]ince 'one country' is the prerequisite for 'two systems,' and this 'one country' is obviously a socialist one, how can we formally separate 'country' and 'socialism' in China's Constitution?" (Jiang 2010: 38). Jiang argues that it is necessary to "break away from legal formalism," "to step down from the clouds of metaphysics," and to understand constitutional questions against "China's political reality, history, and cultural traditions" (Jiang 2010: $38,42)$. Jiang cites Deng Xiaoping as an authority for the realistic view of the Communist Party's role in Hong Kong. Deng believed that Hong Kong should not exercise autonomy through a legislature-led model, but instead be governed by "patriotic" chief executives. Relying on this statement, Jiang contends that "the primary fundamental law in the Basic Law is the rule of patriots in Hong Kong," which is effected by the "leadership of the party" (Jiang 2010: 40). Ergo, the CCP should play a leading role in Hong Kong.

Third, Chinese anti-formalism constitutes an ideological strategy that legitimises China's state-sanctioned political ideology and the Communist Party's approach to the rule of law. Anti-formalist arguments seek to demonstrate that political factors belong inevitably to adjudication and that, as a consequence, the Communist Party's supervision of the judiciary is a legitimate means to bring such political factors into the application of law. The aforementioned CCP textbook on the socialist rule of law conception explains, with reference to American sociological jurists and legal realists, that in the West "there has never existed a judiciary that was truly independent from politics." (22) The lesson is that "the political has always maintained its control and influence over the judiciary." (23) The CCP's ideological project is supported by insights from Sinified Marxism. A universitylevel textbook on jurisprudence that is part of the national core curriculum recognised by the Chinese Ministry of Education contends that Marxism is "the most advanced and scientific legal theoretical framework in the history of mankind" (Zhang 2011: 25). As is the case with sociological and realist jurisprudence, Marxist jurisprudence is based on the study of "practice" (shijian 实践) rather than bourgeois abstractions (Zhang 2011: 21, 28). Such statements not only provide intellectual justifications for accepting China's political realities, but also send a political message about the undesired nature of Western liberal legal and political thought in China.

Fourth, Chinese anti-formalism sometimes associates legal formalism with foreign countries and with the "West" in particular, thereby paving the way for the critique of Western-inspired liberal reforms in China. Professor Deng Zhenglai, a social theorist who taught at Fudan University before his passing in 2013, argued in a seminal book that Chinese "legal dogmatism" had been derived from continental Europe (and from Japan and Taiwan, which had been influenced by European law) (Deng 2008: 65). In Deng's view, Chinese law reformers had received Western legal ideals uncritically, turning them into the moral criteria against which Chinese law and legal development were evaluated (Deng 2008: 108-9). Other Chinese scholars have raised similar concerns. Professor Jiang Shigong notes that "the state of Chinese legal scholarship has been especially preoccupied with legal formalism in order to quickly adapt to international standards" (Jiang 2014: 1999).

The above-described anti-formalist arguments were particularly influential in the 1990s and early 2000s, when most Chinese legal scholarship focused on doctrinal research, as had been true of Western jurisprudence a century earlier. Although the anti-formalist critique did not become the mainstream position in China (Zhu 2001), it remains an important talking point in contemporary Chinese legal scholarship, where it maintains some of its original iconoclastic nature. In a recent debate on the possibility of developing a

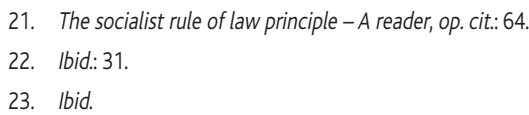

21. The socialist rule of law principle - A reader, op. cit:: 64

23. Ibid 
specifically Chinese form of jurisprudence, Wang Ruolei, an associate professor at the Central Party School, made use of a decidedly legal realist strategy to discredit the received mode of Chinese jurisprudence. Wang mocked the circular definitions of the "old generation of jurists," who viewed "the rule of law as democracy, constitutionalism, and human rights" and "democracy as the rule of law, constitutionalism, and human rights" (Wang 2016: 90). Instead of getting tangled up in such conceptual fallacies, Wang advocated the theoretically well-informed study of "China's contemporary realities" (Wang 2016: 89).

\section{Anti-formalism in Chinese theories of adjudication}

Perhaps the most practical form of Chinese anti-formalism concerns the Party's guidance to judges and other law enforcement officials. To be sure, anti-formalist legal theory, as it is developed in legal scholarship and in Party textbooks, does not translate directly into legal practice. Instead, anti-formalist legal theory provides an ideological justification (philosophical therapy, as it were) for decision-making in courts (Luban 1996: 57-8). Anti-formalist language also sends a message about the undesirability of autonomous legal reasoning - the argument is that politics cannot be separated from law — (24) although judicial autonomy and anti-formalism are not mutually exclusive concepts. The afore-mentioned CCP textbook on the socialist rule of law conception states that "[l]aw enforcement must (...) resolutely prevent and overcome formalism" (xingshizhuyi 形式主义). (25) The textbook does not spell out what overcoming formalism in law enforcement entails. It does, however, introduce an anti-formalist concept to law enforcement: the requirement to "serve the overall circumstances" (fuwu daju 服务大局). On the highest level of abstraction, "overall circumstances" are equivalent to the "fundamental interests of the Party and the state." (26) To serve the "overall circumstances" is to fight against crime and to promote social justice, social harmony, and stability. It is to adhere to Marxism, Deng Xiaoping Thought, the "Three Represents" theory and all the other theoretical concepts advocated by the Party. To serve the overall circumstances is also to protect the Party's efforts in economic, political, cultural, and societal construction, and to safeguard national security-and many other things. (27)

The concept of "overall circumstances" can be seen to perform an antiformalist role in the Party's approach to law application and law enforcement. The concept implies that the literal meaning of a legal rule is insufficient for reaching an appropriate decision in an individual case. Instead of merely relying on the meaning-based interpretation of a legal rule, law enforcement officials should consider the "overall circumstances" relating to the case. This message is strengthened by the textbook's critique of "legal dogmatism" (fatiaozhuyi 法条主义), which is made with direct reference to American sociological jurisprudence and legal realism, as mentioned above. ${ }^{(28)}$ The textbook cites approvingly the views of Benjamin Cardozo (1870-1938), one of the most prominent American jurists and a Supreme Court Justice. Cardozo (1921: 112) argued that adjudication must weight "logic, and history, and custom, and utility" against "the comparative importance or value of the social interests that will be thereby promoted or impaired." (29) Following Cardozo, "overall circumstances" can be seen to stand for all socialist desiderata that should be considered in adjudication.

However, the Party's views on adjudication are far from unambiguous, even by the elusive standards of global sociological jurisprudence and legal realism. While the textbook instructs Party cadres to "resolutely (...) overcome formalism," (30) it also explicitly embraces a "formal conception" (xingshi yiyi 形式意义) of the law. The textbook urges Party cadres to perfect China's socialist legal system "in the formal sense" by ensuring the completeness of the legal system, the well-regulated and systematic nature of legal regulations, and the internal coherence of these regulations. ${ }^{(31)}$ The textbook also states that it is "not possible to 'serve' the overall conditions by violating laws and regulations." (32) As such, the simultaneous critique of formalism and the endorsement of formal law can be coherent. The bad kind of formalism (xingshizhuyi 形式主义) in the textbook may well refer to the authorities' out-of-touch, out-of-tune (even "decadent") attitude to law enforcement, whereas the good kind of formalism may refer to the internal rationality and autonomy of the legal system. Law-in-books should be as consistent as possible, but its application by judges and other officials should respond to the "overall circumstances," and in particular to the CCP's instructions. A commitment to formal law does not preclude the contention that rules ought to be interpreted according to their purpose (Stone 2002: 196).

Nevertheless, the CCP's ideological missives also enable less coherent interpretations. The Party's textbook on socialist law distinguishes between "the overall circumstances" and the law, while at the same time insisting that they are the same thing. "Handling matters strictly according to the law" is to serve the overall circumstances, as is "resolutely opposing (...) non-observance and lax implementation of laws." (33) These statements suggest that the meaning of formal law can be established without the need to apply "overall circumstances" in legal reasoning. In other words, "overall circumstances" may not be within the law in the same way as the "social interests" outlined by Cardozo (1921:112) are. Instead, they are the external criteria against which the results of adjudication are measured. This impression is strengthened by the textbook's distinction between the "legal effect" (falü xiaoguo 法律效果) and the "political and social effect" (zhengzhi xiaoguo, shehui xiaoguo 政治效果, 社会效果) of a judicial decision. While the legal effect of a decision is of "primary importance," it is the "political and social effect" that provides the "ultimate criterion" for law enforcement. ${ }^{(34)}$ Yet, the textbook also states that the constitution and the law are the supreme sources of normativity, as are the Party's cause and the People's interests. ${ }^{(35)}$

Finally, conservative-minded Chinese legal scholars sometimes argue that judges should discard formal law when this is the right thing to do. As already mentioned, Chinese sociological jurists do not advocate casting aside all formal legal rules and processes. Zhu Suli, for instance, acknowledges that judges should "even stick to procedural justice because the cost of substantive justice is too high" (Zhu 2016: 123). Nevertheless, Zhu also in-
24. Ibid.: 30-1.
25. Ibid.: 76 .
26. Ibid.: 99.
27. Ibid: $104-6$
28. Ibid.: 30 .
29. Ibid.
30. Ibid: $75-6$
31. Ibid.: 64.
32. Ibid:109.
33. Ibid.
34. Ibid.: 110 .
35. Ibid. 
structs judges "to settle disputes well" after considering all possible solutions and "not just (...) abide by their duties and implement extant legal rules" (Zhu 2016: 123). In this regard, Zhu praises a figure in one of his empirical studies: a rural judge who invents extra-legal remedies for the plaintiff forgetting "certain basic rules" of formal law, such as the principle that there should be no trial without a complaint (Zhu 2016: 124).

The anti-formalist, pragmatic approach to adjudication conforms to the consequentialist, wealth-maximising political ideology popular in China, which presumes that formal rights and other legal institutions are ultimately a means to an end (Zhu 2016: 123). Reflecting this perception, Communist Party cadres sometimes suggest that formal law, even in its socialist form, cannot be regarded as an autonomous field of knowledge. ${ }^{(36)}$ Such anti-formalist statements should be seen in the context of equally prominent formalist statements about adjudication and law enforcement. As was pointed out above, the CCP and Chinese leaders instruct Party cadres and government officials to observe the laws strictly. There are readily understandable reasons for such incoherent and even paradoxical uses of language in the Party's ideological texts. The CCP cannot instruct judges and other government officials to discard formal law, because the Party governs China (at least partly) through formal law. The Party wishes to restrict discretion in decision-making, for instance, in order to ensure that local protectionism does not subvert the Party's economic goals. (37) As a consequence, and in contrast to some Western anti-formalists (Posner 1996: 19), the Communist Party does not seek to delegate boundless discretionary powers to judges. The Party also regards formal equality, delivered through the people's courts, as a social good in its own right. ${ }^{(38)}$ Emphasis on formal legal rules is a viable governance strategy for the Party, because it is nearly invisible on the level of formal law (Sapio 2010: 246-8).

Nevertheless, formal law, even in its socialist form, allows potential legal challenges against the Party's power. The Party cannot allow judges to apply law against "the fundamental interests of the Party and the State," (39) lest liberal-minded judges expand the scope of civil and political rights too far into the political arena. As a consequence, the Party sends ambiguous messages about the role of formal law and the preferred methods of adjudication, making it apparent that the relationship between the Party and the law should be seen as an unsettled and highly politicised matter (Seppänen 2016: 78). The ambiguous nature of the Party's ideological statements on formal law has been noted and criticised by mainstream Chinese legal scholars, who seek to strengthen the autonomy of the Chinese judiciary (Tong 2011).

\section{"Writing poems at the request of the Emperor"}

Finally, it may be asked whether the above-described uses of anti-formalism constitute a specifically "Chinese" form of jurisprudence. As may be expected, the answer to this question depends on the ideological sensibilities of an individual scholar. Chinese government ideologues and conservativeminded scholars hope that the study of China's social realities will produce a Chinese form of jurisprudence that can compete with Western liberal legal thought. ${ }^{(40)}$ Scholars who are not interested in competing with Western liberalism do not find it necessary or even possible to develop a uniquely Chinese jurisprudence. Liberal-minded scholars, such as Professor Xu Aiguo at Peking University, argue that any form of jurisprudence worth its name cannot be based on a presumption of national unity. In Xu's view, Chinese legal scholars developing such theories "write poems at the request of the Emperor" (yingzhi 应制): "When officials speak of the necessity of developing a market economy, [Chinese] jurists explain that market economy is an economy under the rule of law (...); when the officials talk about Chinese characteristics, [Chinese] jurists write about the rule of law and native resources" (Xu 2016: 194).

Even among party ideologues, theoretical ambitions are considerably lowered as one descends from the visionary heights of the Party's leadership to the grassroots level of junior law professors, who are tasked with inventing original "Chinese" legal theoretical insights. At the highest level of ideological leadership, President Xi Jinping is able to declare that "socialism with Chinese characteristics (...) offers a new option for other countries and nations," (41) as well as to instruct scholars to develop "a system of philosophy and social sciences with Chinese characteristics that incorporates the country's socialist practices." (42) At the managerial level, politically attuned senior professors and directors of academic institutions may still adhere to the optimistic visions of the Party's highest leadership. According to one academic manager, "the CCP (...) has developed and perfected the theory of the socialist rule of law with Chinese characteristics." (43) At the same time, managers may also acknowledge problems in the implementation of these visions. From the managerial perspective, it appears that "it has been difficult for law as a discipline to meet the practical needs" of Chinese society. ${ }^{(44)}$ At the grassroots level, junior scholars see almost insurmountable obstacles to developing a Chinese form of jurisprudence. Wang Ruolei of the Central Party School argues that theoretical innovation in Chinese legal academia is hampered by a poor academic environment. Whereas Western legal scholarship progresses persistently due to "constant reflection, criticism, and correction of previous hypotheses and conclusions," in China "even a good article fizzles out without anybody contesting, critiquing, or responding to it" (Wang 2016: 91). The lack of a discursive community has precluded the formation of uniquely Chinese methods, conclusions, and paradigms of jurisprudence, which Wang believes to be essential for the formation of an academic school of thought (Wang 2016: 91).

Ironically, ideological repression also constrains Chinese legal scholars' efforts to develop a legal thought that could plausibly challenge liberal political and legal thought. In particular, attempts to make sense of "China's realities" are obstructed by ideological taboos that prevent scholars from addressing the merits of China's governance system in frank and honest terms. The same is true of legal theoretical innovation. Although Chinese legal theorists allege that China's Marxist jurisprudence proceeds from "the

36. See, e.g., the statement by Zhou Qiang 周强, the President of the Supreme People's Court: "要敢 于向西方 “司法独立'等错误思潮亮剑” (Yao ganyu xiang Xifang 'sifa duli' deng cuowu sichao liangjian, We must dare to take out the sword against erroneous Western ideological trends such as 'judicial independence'), 14 January 2017, http://news.sina.com.cn/c/nd/2017-01-14/docifxzqnim4410469.shtml (accessed on 12 March 2018); The socialist rule of law principle - A reader, op. cit.: 30

37. The socialist rule of law principle - A reader, op. cit.: 102

38. Ibid:: 88.

39. Ibid.: 99.

40. "Speeches in the symposium on the tasks of philosophy and social sciences," art. cit.

41. "Socialism with Chinese characteristics enters new era: Xi," Xinhua, 18 October 2017, http://www.xinhuanet.com//english/2017-10/18/c_136688475.htm (accessed on 2 November 2017).

42. "Xi stresses philosophy, social sciences for socialist development, highlights Chinese characteristics," art. cit.

43. "Speeches in the symposium on the tasks of philosophy and social sciences," art. cit.

44. Ibid. 
concrete to the abstract" (Zhang 2011:28), in practice, Chinese legal scholars are advised to progress in the opposite direction. In the aforementioned meeting between President $X i$ and Chinese social scientists, a legal scholar first instructed Chinese legal scholars to "fully understand the great significance of the theory of socialism with Chinese characteristics," and (only) then to "implement it in the legal profession, promoting innovations in legal theory." (45) Similarly, the afore-mentioned textbook on jurisprudence decrees without much nuance that dialectical materialism must be at the core of Chinese jurisprudence (Zhang 2011: 22). The anti-formalist impulse to "seek truth from facts" is therefore tempered by the formalist nature of Chinese socialism. ${ }^{(46)}$

Perhaps the most fundamental obstacle to developing a specifically Chinese form of jurisprudence relates to the globalised nature of legal thought. Whereas Chinese legal scholars have been instructed to develop original "Chinese" legal theoretical insights, American and Scandinavian scholars never set out to produce specifically "American" or "Scandinavian" approaches to law. Geographical labels were applied to American and Scandinavian scholarship only retrospectively, mostly for pedagogic reasons and with many caveats. For all the talk about the creative agency of individual scholars, Chinese legal academia is thoroughly globalised. In addition to ideological divisions, Chinese legal scholars are divided according to the countries in which they received their graduate legal education. Scholarship produced in the American post-realist genre by graduates from American universities is seen to differ considerably from European-style legal scholarship, which focuses on the textual analysis of formal law. ${ }^{(47)}$ And, needless to say, dialectical materialism, the supposed core of Chinese jurisprudence, originates in European social theory and continues to be defined with reference to Marxist classics even in its Sinicised form (Zhang 2011: 25-30).

Because of the global nature of legal academia, the persuasive force of legal theoretical arguments is measured globally, even when they purport to relate to a single country. Chinese legal scholars are well aware of this fact. Zhu Suli (2004: 6), Xu Aiguo (2016: 171), and Wang Ruolei (2016: 86) acknowledge that Chinese legal scholars will find it difficult to be persuaded by local legal theoretical arguments if these arguments seem incapable of standing up to global legal theoretical claims. In Wang's opinion (2016: 90), the first step towards the development of a Chinese form of jurisprudence is not the examination of China's social realities but the profound study of H.L.A. Hart, the English legal philosopher.

\section{Conclusion: Towards a Chinese jurisprudence?}

It is easy to understand why a number of Chinese legal scholars and government ideologues are drawn to anti-formalist legal thought. The key insights of anti-formalism ring true in the Chinese context. If anywhere, surely the legal realist insight that formal state law and legal institutions are potentially out-of-step with social realities (Horwitz 1992: 188) is relevant in contemporary China. It also seems plausible that the study of China's development experience will yield original legal theoretical insights.

Nevertheless, anti-formalism offers no easy shortcuts for developing such insights. Of course, one may apply a geographical label to Chinese jurisprudence (as this article has done), just as one may apply it to French and Estonian jurisprudence. Anti-formalism certainly takes on a specific and perhaps even unique form in China, where legal scholars have to adjust their theoretical views to the country's idiosyncratic ideological landscape. It is also clear that the social effects of legal theoretical arguments are different in China than elsewhere. Chinese anti-formalism supports the country's authoritarian political system and its experimental approach to economic regulation, whereas Western twentieth-century anti-formalism was part of the progressive, social democratic movement. In this sense, Chinese legal science is already indigenised, as is of course Finnish legal science and Swedish legal science.

Nevertheless, an anti-formalist statement about the law, even when described as a "Chinese" anti-formalist statement, is interpreted as an argument in the global langue of legal theory-a language that offers plenty of counterarguments against any single anti-formalist theoretical statement (Kennedy 2006b). Does it make sense to maintain that the predictability of the legal process is just one consideration in an open-ended pragmatic calculation of means and ends? How can concrete social realities be weighed against justice goals? There is a lively, century-long debate about these questions. Denying Chinese legal scholars access to this discourse-and preventing them from being persuaded by arguments derived from itwould be difficult in contemporary China.

Indeed, even the nationalistic tendency of Chinese anti-formalism reflects its foreign linkages. As is the case with Chinese neo-conservative legal scholars today, Western sociological jurists and legal realists tended to see legal formalism as a foreign-born problem (Kennedy 2006b: 48-9). American sociological jurists thought that the formal legal concepts of American law, which were out of touch with social realities, were alien to American traditional society (Pound 1917: 211). When the United States government began to export American legal thought to developing countries in the 1950s and 60s, the working assumption was that American jurisprudence was more responsive to local social concerns than the formalist legal thought in developing countries (Kennedy 2006a: 104-5). Deriding foreigners for formalism has a long pedigree in global legal thought.

\section{ISamuli Seppänen is Assistant Professor at the Faculty of Law of the Chinese University of Hong Kong. \\ Faculty of Law of the Chinese University of Hong Kong, Shatin, New Territories, Hong Kong (sseppanen@cuhk.edu.hk).}

Manuscript received on 4 December 2017. Accepted on 9 April 2018.

45. "Speeches in the symposium on the tasks of philosophy and social sciences," art. cit.

46. The tension between formalist and anti-formalist arguments in Marxist legal thought is not, of course, limited to China (Stone 2002: 181).

47. Interview with two US-trained legal scholars, June 2017, Beijing (notes on file with author). 


\section{References}

ACKERMAN, Bruce, A. 1974. "Law and the Modern Mind by Jerome Frank." Daedalus 1974(103): 119-30.

CARDOZO, Benjamin. 1921. The Nature of the Judicial Process. New Haven:Yale University Press.

GENY, François. 1919. Méthode d'interprétation et sources en droit privé positif: essai critique (Interpretation method and sources in positive private law: critical essay). Paris: F. Pichon et Durand-Auzias.

DENG Zhenglai 邓正来. 2008. 中国法学向何处去——建构“中国法律理想 图景”时代的论纲 (Zhongguo faxue xiang he chu qu: jiangou 'Zhongguo falü lixiang tujing' shidai de lun gang, Whither Chinese law: Outline for an era to construct an 'ideal image of Chinese law'). Beijing: Shangwu yinshuguan.

DENG, Zhenglai (Lin Xi transl). 2014. Rethinking Chinese Jurisprudence and Exploring its Future: A Sociology of Knowledge Perspective. New Jersey: World Scientific Publishing Company.

HOLMES, Oliver Wendell Jr. 1897. "The Path of the Law." Harvard Law Review 1897(10): 457-78.

HORWITZ, Morton J. 1992. The Transformation of American Law, 18701960: The Crisis of Legal Orthodoxy. Oxford: Oxford University Press.

JIANG Shigong 强世功. 2003. 法制与治理：国家转型中的法律 (Fazhi yu zhili: Guojia zhuanxing zhong de falü, Legal system and governance: law in a transforming state) Beijing: Zhongguo zhengfa daxue chubanshe.

JIANG, Shigong. 2010. "Written and Unwritten Constitutions: A New Approach to the Study of Constitutional Government in China." Modern China 2010(36): 12-46.

JIANG, Shigong. 2014. "How to Explore the Chinese Path to Constitutionalism? A Response to Larry Cata Backer." Modern China 2014(40): 196-213.

JHERING, Rudolph von (Isaac Husik transl). 1913. Law as a Means to an End. Boston, MA: Boston Book Company.

KENNEDY, David. 2006a. "The 'Rule of Law,' Political Choices and Development Common Sense." In David M. Trubek and Alvaro Santos (eds.), The New Law and Economic Development. Cambridge: Cambridge University Press. 95-173.

KENNEDY, Duncan. 1976. "Form and Substance in Private Law Adjudication." Harvard Law Review 1976(89): 1685-778.

KENNEDY, Duncan. 2001. "Legal Formalism." In Neil J. Smelser and Paul B. Baltes (eds.), Encyclopedia of the Social \& Behavioral Sciences: Volume 13. Amsterdam: Elsevier. 8634-8.

KENNEDY, Duncan. 2006b. "Three Globalizations of Law and Legal Thought: 1850-2000." In David Trubek and Alvaro Santos (eds.), The New Law and Economic Development: A Critical Appraisal. Cambridge: Cambridge University Press: 19-73.

KOSKENNIEMI, Martti. 2001. The Gentle Civilizer of Nations: The Rise and Fall of International Law 1870-1960. Cambridge: Cambridge University Press.

KRONCKE, Jedidiah J. 2016. The Futility of Law and Development: China and the Dangers of Exporting American Law. Oxford: Oxford University Press.

LLEWELLYN, Karl. 1930. "A Realistic Jurisprudence: The Next Step." Columbia Law Review 1930(30): 431-65.

LUBAN, David. 1996. "What's Pragmatic about Legal Pragmatism." Cardozo Law Review 1996(18): 43-73.

LUNDSTEDT, A. Vilhelm. 1956. Legal Thinking Revised: My Views on Law. Stockholm: Almqvist \& Wiksell.

MALMINEN, Toni. 2007. "So You Thought Transplanting Law is Easy? Fear of Scandinavian Legal Realism in Finland, 1918-1965." In Jaakko Husa, Kimmo Nuotio, and Heikki Pihlajamäki (eds.), Nordic Law: Between Tradition and Dynamism. Oxford: Intersentia.

MANNING, John. 1999. "Constitutional Structure and Statutory Formalism." University of Chicago Law Review 1999(66): 685-97.
POUND, Roscoe. 1908. "Mechanical Jurisprudence." Columbia Law Review 1908(8): 605-23.

POUND, Roscoe. 1910. "Law in Books and Law in Action." American Law Review 1910(44): 12-36.

POUND, Roscoe. 1917. "The End of Law as Developed in Juristic Thought. II." Harvard Law Review 1917(30): 201-25.

POSNER, Richard A. 1996. "Pragmatic Adjudication." Cardozo Law Review 1996-1997(18): 1-20.

SCHAUER, Frederick. 1988. "Formalism." Yale Law Journal 1988(97): 509-48. SAPIO, Flora. 2010. Sovereign Power and the Law in China. Leiden: Brill. SEPPÄNEN, Samuli. 2016. Ideological Conflict and the Rule of Law in Contemporary China. Cambridge: Cambridge University Press.

SEPPÄNEN, Samuli. 2014. "Ideological Renewal and Nostalgia in China's 'Avant-Garde' Legal Scholarship." Washington University Global Studies Law Review 2014(13): 83-125.

SHALAKANY, Amr. 2001. "Sanhuri and the Historical Origins of Comparative Law in the Arab World (or How Sometimes Losing your Asalah can be Good for You)." In Annelise Riles (ed.), Rethinking the Masters of Comparative Law. Oxford: Hart. 152-88.

STONE, Martin. 2002. "Formalism." In Jules Coleman and Scott Shapiro (eds.), The Oxford Handbook of Jurisprudence and Philosophy of Law. Oxford: Oxford University Press. 166-205.

SUN, Yat-sen (Frank W. Price transl). 1927. San Min Chu I: The Three Principles of the People. Shanghai:The Commercial Press.

TONG Zhiwei 童之伟. 2011. “法治：怎么表达也很紧要” (Fazhi: Zenme biaoda ye hen jinyao, The rule of law: How to express it is also critical). http://www.aisixiang.com/data/39932.html (accessed on 12 March 2018).

TWINING, William. 2014. Karl Llewellyn and the Realist Movement. Cambridge: Cambridge University Press.

UPHAM, Frank. 2006. "Who Will Find the Defendant if He Stays with His Sheep? Justice in Rural China." Yale Law Journal 2005(114): 1675-718.

WANG, Hui. 2006. China's New Order: Society, Politics, and Economy in Transition. Harvard University Press: Cambridge, MA.

WANG, Hui. 2009. The End of the Revolution: China and the Limits of Modernity. London: Verso.

WANG Ruolei 王若磊. 2016. “不曾生，何谈死? 中国法理学的死亡及其生 的可能” (Bu ceng sheng, he tan si? Zhongguo falixue de siwang ji qi sheng de keneng, If it hasn't been born, why talk about its death? The death of Chinese jurisprudence and the possibility of its revival). Jining xueyuan xuebao 2016/37(4): 85-92.

XIA, Yong. 2011. The Philosophy of Civil Rights in the Context of China. Leiden: Martinus Nijhoff Publishers.

XU Aiguo 徐爱国. 2002. “为法治而斗争: 批苏力的《法治及其本土资源》” (Wei fazhi er douzheng: Pi Su Li de 'Fazhi ji qi bente ziyuan', Struggle for the rule of law: A critique of Zhu Suli's 'Rule of law and its native resources'). Beida falü xinxi wang. http://article.chinalawinfo.com:81/article_print.asp?articleid=19835 (accessed on 2 November 2017).

XU Aiguo 徐爱国. 2016. “论中国法理学的'死亡”' (Lun Zhongguo falixue de 'siwang', The 'death' of Chinese jurisprudence), Zhongguo falü pinglun 2016/10(2): 189-97.

ZHANG Wenxian 张文显 (ed.). 2011. 法理学 (Falixue, Jurisprudence). Beijing: Gaodeng jiaoyu chubanshe.

ZHU Suli 朱苏力. 2001. “也许正在发生一一中国当代法学发展的一个概览” (Yexu zhengzai fasheng: Zhongguo dangdai faxue fazhan de yige gailan, Possible developments: An outlook of the development of contemporary Chinese jurisprudence). Bijiaofa yanjiu 2001(3): 1-9.

ZHU Suli 朱苏力. 2004. 法治及其本土资源 (Fazhi ji qi bentu ziyuan, Rule of law and its native resources). Beijing: Zhongguo Zhengfa daxue chubanshe.

ZHU, Suli. 2016. Sending Law to the Countryside. Singapore: Springer. 